\title{
Fostering collective intelligence education
}

\author{
Jaime Meza ${ }^{1, *}$, Josep M. Monguet ${ }^{1,}$ Francisca Grimón ${ }^{2}$, Alex Trejo ${ }^{3}$ \\ ${ }^{1}$ Universitat Politècnica de Catalunya, Barcelona, Spain \\ ${ }^{2}$ Universidad de Carabobo, Valencia, Venezuela \\ ${ }^{3}$ Onsanity, Barcelona, Spain
}

\begin{abstract}

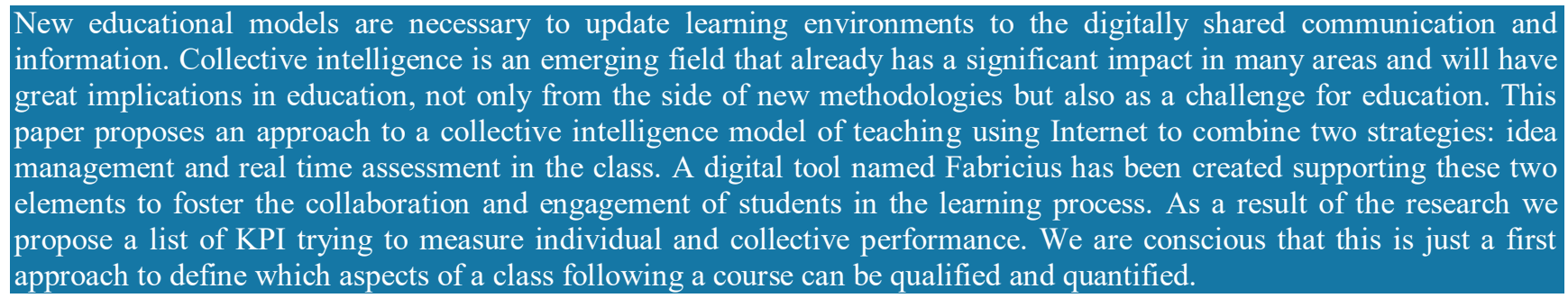

Keywords: Collective intelligence Education, learning, patterns, KPI.

Received on 26 November 2015, accepted on 04 May 2016, published on 15 June 2016

Copyright (C 2016 Jaime Meza et al., licensed to EAI. This is an open access article distributed under the terms of the Creative Commons Attribution licence (http://creativecommons.org/licenses/by/3.0/), which permits unlimited use, distribution and reproduction in any medium so long as the original work is properly cited.

doi: 10.4108/eai.15-6-2016.151448

\section{Introduction}

Education is a huge and multidisciplinary field that has been studied from different epistemological perspectives looking for new challenges to improve student's performance. Therefore educational institutions are constantly searching new models to improve the results of their learning processes.

There is a lot of evidence about the fact that multimedia and Internet based educational tools have potential to improve student learning[1] and there is also evidence about the advantages of distance learning [2]. However education and capacitation in a networked society is not just an extension of the usual capacity building. Besides classical technological competences new ones linked to accessing and processing knowledge are necessary, particularly collective intelligence. New capabilities cannot be acquired through the old ways of education: collective capacities building needs new contents and methods[3]

Collective intelligence CI is defined as the capacity of human groups to engage in intellectual cooperation in order to create, innovate and invent [4]. Although CI is not a new

*Corresponding author. jaimemeza1@gmail.com idea, its combination with ICT tools is setting this paradigm as an exciting and emerging area [5][6]. Several authors have reported about collective intelligence and its impact with the ICT tools in the educational field [7],[8],[9],[10],[11], moreover, some researchers have generated papers for refer to the measure of collective intelligence. Engelbart (1995) propose the Collective IQ, term proposed by refers to the measure of a group's collective capacity[12], Woolley et al. (2010) put forward the Factor C [13], Barlow, J. B., \& Dennis, A. R.(2014) conclude that a Factor $\mathrm{C}$ defined by Woolley et al. (2010) is not a general factor of collective intelligence inherent to groups under all conditions, but it is a measure of a group's general ability to work well in face-to-face settings [14].

This research describes the teaching model based on Fabricius, an ICT tool developed with the general idea of integrating into one framework the two relevant aspects in learning by doing: management of ideas and real time assessment. The general objective of our research is to contribute in the identification of collective intelligence patterns in the behaviour of the class.

The first part of this article is devoted to the introduction of collective intelligence education concepts and the Internet 
available tools to implement it. The second part presents the design of the model Fabricius and third part outlines the results of its implementation. The paper concludes that a collective intelligence strategy based on Internet tools may facilitate and improve teaching through collective activities and that it is possible to define some kind of KPI to qualify and quantify collective as well as individual performance

\section{Collective intelligence education.}

Collective intelligence in the field of education has been reported by several authors[15][8][16]. A significant amount of research in the last decade refers to collective intelligence connected with information technologies and located in education [7]. This interest in such advanced research contrasts with the fact that the educational systems haven't evolved so much during the lasts decades. The incorporation of collective intelligence in education involves not only a technological change or a transformation in the attitude of teachers, but also a redefinition of education [16]. [13]. If the concept and models of collective intelligence evolve it should leverage a system of global learning, content and networking. We see currently some indicators of this tendency like MOOC or social networks applied to education.

The collective intelligence in teaching-learning processes affects both teachers and students: evaluations, educational materials or ideas management can use the web as a learning platform strengthening sharing, contribution and collaboration. In addition to the content provided by the teacher, collective intelligence strategies allow students conducting semi-independent research in class[8].

Collective intelligence allows permanent, cooperative and collective learning, guiding students in acquiring knowledge within virtual communities, reflecting a new relationship with knowledge. There is a shift in focus from the pedagogical design of learning content to collectively create and share content, which opens new fields of research for collective intelligence[9]. In their research Thompson et al., (2014) indicate that there is evidence that students can be autonomous in their learning and also participate collaboratively [10].

With the growing of cyberspace, a lot of Internet tools have been designed for catching the knowledge from small and big groups (wikipedia, digg, google, facebook and so on), in this context, we looked for tools that integrate ideas management, decision making process and also pattern recognition for forecasting behaviour of the groups. In the Table 1 we summarize a sampling of Collective Intelligence Internet tools with focus on the educational field.
Table 1. Sumary of Collective Intelligence Internet tools

\begin{tabular}{|c|c|}
\hline Tool & Description \\
\hline $\begin{array}{l}\text { Software } \\
\text { catalog:Capterra[17] }\end{array}$ & $\begin{array}{l}\text { A ranking software with } \\
\text { contributions from the internet } \\
\text { users that whit the term "Idea } \\
\text { Management" showed } 52 \\
\text { products. Most of the products } \\
\text { implement processes for } \\
\text { declaring challenge and } \\
\text { propose and vote ideas. }\end{array}$ \\
\hline Project: Catalyst[18] & $\begin{array}{l}\text { An example of an open source } \\
\text { project aiming to improve } \\
\text { collective sense making and } \\
\text { creative ideation for the } \\
\text { common good in large-scale } \\
\text { online debates about social } \\
\text { innovation. }\end{array}$ \\
\hline Software tool: QLIM[19] & $\begin{array}{l}\text { It is an interactive } \\
\text { questionnaire management } \\
\text { tool, which use the real time } \\
\text { Delphi model in its } \\
\text { implementation. }\end{array}$ \\
\hline Health Consensus[20] & $\begin{array}{l}\text { It's a tool initially designed to } \\
\text { support participative } \\
\text { processes of experts in the } \\
\text { health area based on a } \\
\text { digitally adapted Delphi model. } \\
\text { It has been used to manage e- } \\
\text { learning clinical cases. }\end{array}$ \\
\hline
\end{tabular}

\section{Fabricius. Approaching collective intelligence learning.}

Considering the theoretical trends and tools identified in collective intelligence in education, a prototype of a teaching model and its ICT tool has been designed, developed, tested and is formally introduced in this section. Fabricius is synthetically drawn in Fig. 1, this combines the individual and collective work from students and experts.

Fabricius may be defined as a digital tool for a teaching method that enables each student individually and collectively in synchronous or asynchronous mode:

- Work with the production and filtering of ideas

- Actively participate in the assessment of the work done by all the students

Moreover the tool collects data of the teaching process that once analyzed through a pattern recognition model allows understanding the behaviour and level of learning of students

As a result of the pattern recognition obtained during the use of the platform the design of the practice may be improved for next application. 


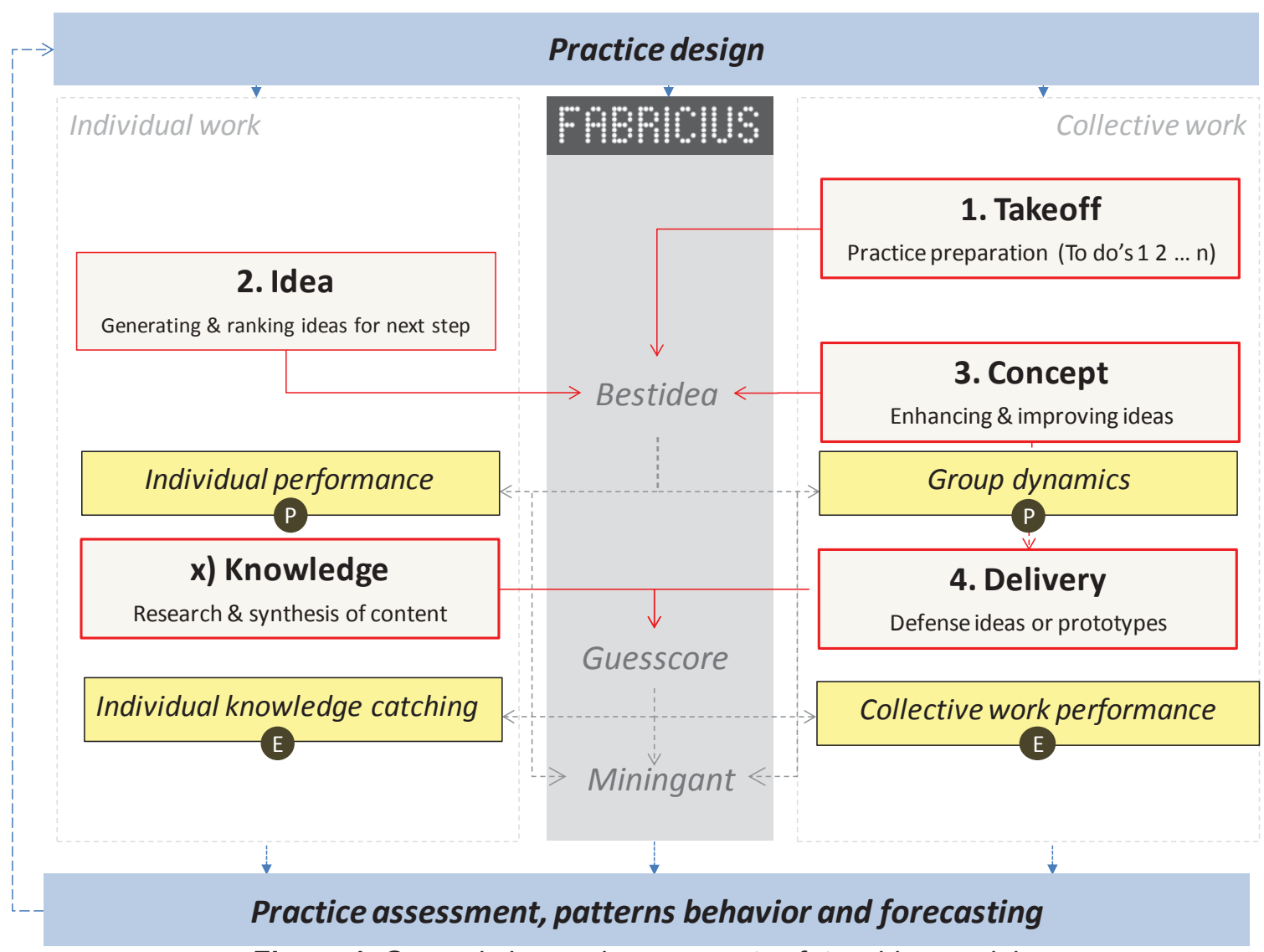

Figure 1. General view and components of teaching model

The central hypothesis of the research is that collective intelligence Internet tools like Fabricius, facilitate open management of ideas, real time collaborative assessment and forecasting of work done in the class, consequently they may help fostering the interaction, collaboration, empowerment and engagement of students in the learning process. The idea came from the Kaizen methodology (change for better), where each practice contributes to improve the next. Outcomes of the process try to improve the students and experts' skills working together in a collective environment. Fabricius is formed by three main elements listed and defined in table 2 and drawn in figure 2.

The elements defined in table 2 are the core of Fabricius, which could be used alone or together, this feature allow setting different kind of parameters according to the nature of the field of knowledge. The typical setting in Fabricius suggest using Besidea, Guesscore and Miningant, where the first stage in the practice resolve is idea's filtering through multiple rounds of valuation, after that, you can use Guessscore to evaluate collectively the winner idea from Besidea. Miningant will allow monitoring the individual and group behaviours, and let us getting real time information.
Table 2. Main elements of Fabricius

\begin{tabular}{|c|c|}
\hline Element & Description \\
\hline Bestidea & $\begin{array}{l}\text { Individual-collective production of ideas.- } \\
\text { Management of the process of proposing, } \\
\text { voting and ranking ideas. It can be used } \\
\text { in asynchronous or in synchronous } \\
\text { mode. }\end{array}$ \\
\hline Guesscore & $\begin{array}{l}\text { Collective real time assessment.- } \\
\text { Individual as well as collective work of } \\
\text { students can be assessed during the } \\
\text { classes through a synchronous real time } \\
\text { collective voting [21],[22],[23]. }\end{array}$ \\
\hline Miningant & $\begin{array}{l}\text { Pattern recognition and forecasting of } \\
\text { individual-collective behaviour .- The } \\
\text { track created by students using Bestidea } \\
\text { and Guesscore incorporate individual and } \\
\text { collective data that conveniently treated } \\
\text { through data mining techniques may } \\
\text { reflect the behaviour of students and } \\
\text { learning process }\end{array}$ \\
\hline
\end{tabular}

Practices are organized following a workflow described in figure 1 and summarized in table 3 (Bestidea: Take off, Idea, Concept. Guesscore: Delivery, Knowledge). Let's note that this is a particular distribution of activities that are pertinent for a learning by doing strategy based on practices but might be not appropriated for other courses. The 
instructive process consists of solving a list of to do's, (normally 4) where the last one is the key activity, while the previous to do's are just for learning and preparing the ground for this.
Just to clarify, we consider individual students, groups of students (4 to 7 members) and the class with all the students enrolled.

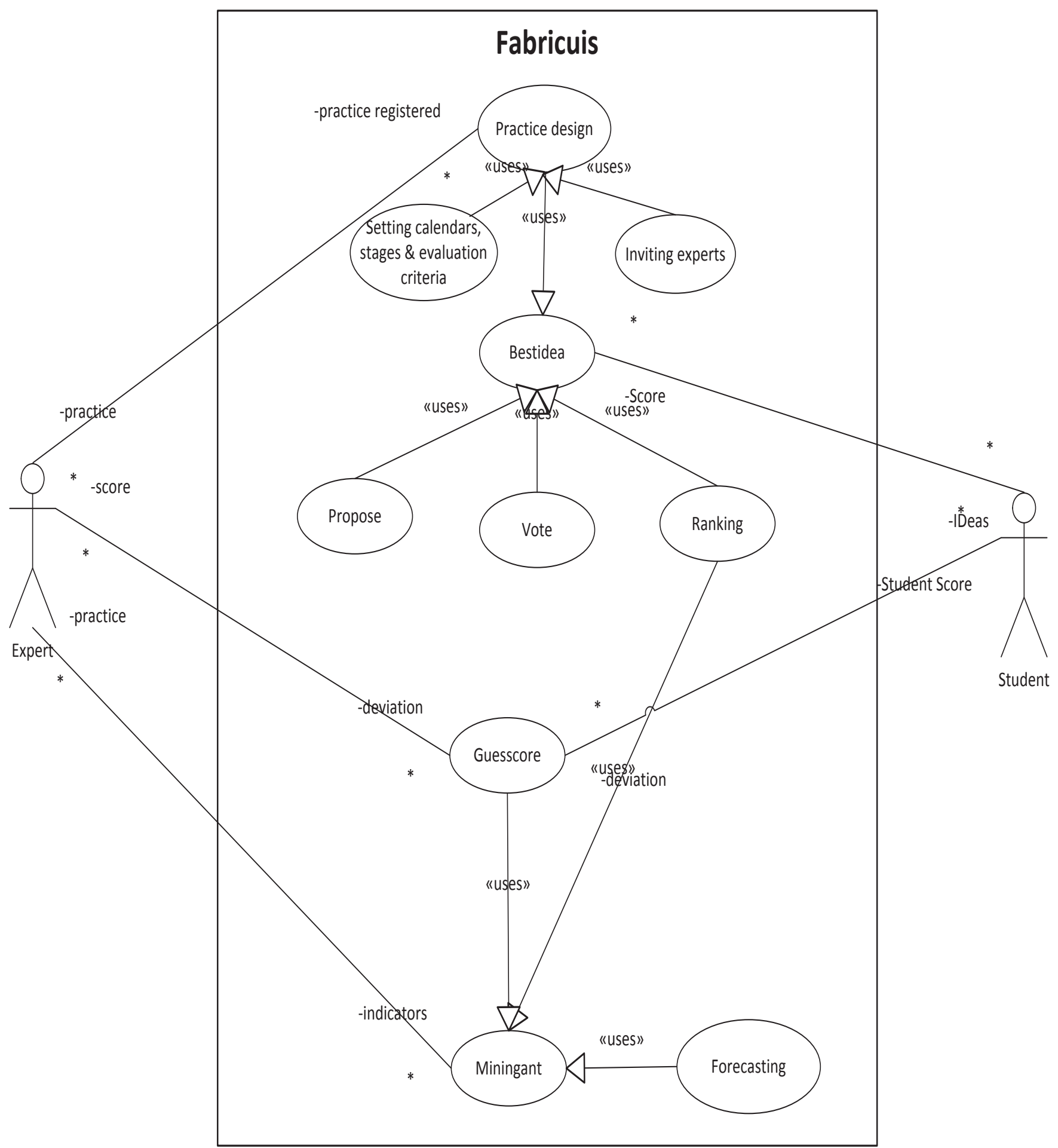

Figure 2. Context diagram (use cases level 0). 
Table 3. Stages of model

\begin{tabular}{|c|c|}
\hline Stage & Description \\
\hline Stage 1, 2 \& 3 & $\begin{array}{l}\text { Working with Bestidea. } \\
\text { The Bestidea component of Fabricius } \\
\text { is used to create the ideas that will be } \\
\text { discussed and evaluated to prepare } \\
\text { the practice }\end{array}$ \\
\hline 1.-Take Off & $\begin{array}{l}\text { The practice begins with a Takeoff } \\
\text { session (synchronous or } \\
\text { asynchronous ) that is composed of: } \\
\text { Statement of practice and Lecture. } \\
\text { Work with to do's (1, } 2 . . \text { until n) using } \\
\text { Bestidea. } \\
\text { To do's are consecutive and each to } \\
\text { do (except the first) is based in the } \\
\text { results obtained in the previous one. } \\
\text { To do's follow the same cycle: 1st } \\
\text { Students propose ideas individually, } \\
\text { 2nd Group votes ideas in order to } \\
\text { prioritize and 3th Winning ideas, one } \\
\text { or more, are inspirations for the next } \\
\text { to do }\end{array}$ \\
\hline 2.-Idea & $\begin{array}{l}\text { Considering what has been learnt } \\
\text { with the work done during Take-off, } \\
\text { each student individually proposes } \\
\text { ideas for the key to do. The } \\
\text { participants in the class will vote all } \\
\text { ideas proposed by their classmates. } \\
\text { Students of the class will be randomly } \\
\text { assigned to vote ideas of any of the } \\
\text { groups participating (Llullian } \\
\text { method[25]), except their own group. } \\
\text { At the end of stage } 2 \text { there exists a } \\
\text { list of individual ideas ordered } \\
\text { according to the relative value voted } \\
\text { by the participants }\end{array}$ \\
\hline 3.-Concept. & $\begin{array}{l}\text { The list of prioritized ideas from stage } \\
2 \text { is the departing point for the } \\
\text { collective generation of a "concept" to } \\
\text { solve the last to do. } \\
\text { Each group will use the same strategy } \\
\text { (NGT[26] as a strategy to elaborate a } \\
\text { concept with a certain degree of } \\
\text { detail) to enhance and extend } \\
\text { previous ideas working ahead } \\
\text { proposing and prioritizing new items } \\
\text { (ideas). Proposing as many items as } \\
\text { the group decides a consistent } \\
\text { concept is gradually elaborated. } \\
\text { At the end of the stage } 3 \text { the group of } \\
\text { students has collectively created the } \\
\text { ideas and items that will allow } \\
\text { proposing and defending a final } \\
\text { Concept. Let's note that the } \\
\text { contributions of students are not } \\
\text { symmetric. }\end{array}$ \\
\hline S & $\begin{array}{l}\text { Working with Guesscore } \\
\text { The Guesscore component of } \\
\text { Fabricius is used to assess the ideas } \\
\text { and the content proposed by the } \\
\text { groups or by students }\end{array}$ \\
\hline
\end{tabular}

4.-Delivery The groups of students defend their final concept for the practice and their classmates and the experts (teachers) assess real time the concept presented. As said before the concept responds to the last to do of the practice. As a result of this assessment each group has a score but each student that has voted has also an individual score depending on the accuracy of their judgments.

X.- Knowledge Each practice consists of the application of some particular content (theories and or techniques) that has been introduced with a lecture and the activities during the Take-off. Each student (or group) is asked to contribute with some original knowledge to the content of the practice. Original knowledge may come in the form of: Interesting people that have applied the content object of the practice, or products and services or any kind of organization that highlights the content.

The student (or group) gets extra point when their proposal has been approved by the expert and is voted by classmates in this assessment stage.

The stages of model showed in Table. 3, generates data that are used to analyze and evaluate the behaviour of the students and the class. Table 4 presents the elements that are measured during the execution of the practice

Table 4. Analytics of the Fabricius Teaching Model

\begin{tabular}{|c|c|}
\hline Element & Description \\
\hline Individual performance & $\begin{array}{l}\text { Measuring individual } \\
\text { contributions during take- } \\
\text { off, idea and concept. }\end{array}$ \\
\hline $\begin{array}{l}\text { Individual knowledge } \\
\text { catching }\end{array}$ & $\begin{array}{l}\text { Measuring individual } \\
\text { accuracy of Guesscore } \\
\text { judgments. }\end{array}$ \\
\hline Group dynamics & $\begin{array}{l}\text { Measuring evolution of } \\
\text { level of consensus } \\
\text { among the group } \\
\text { members during } \\
\text { collective activities. }\end{array}$ \\
\hline Collective work performance & $\begin{array}{l}\text { Score partially corrected } \\
\text { with score from } \\
\text { classmates. }\end{array}$ \\
\hline
\end{tabular}

At the end of each practice the students can access to all the measures and assessments available. Appendix A show some interfaces of Fabricius.

\section{Results applying Fabricius.}

Fabricius is initially intended for the management of learning by doing in degree courses and has been used in 
the areas of design-engineering and pre-primary education teaching (Universitat Politécnica de Catalunya UPCSpain, Universidad de las Fuerzas Armadas ESPE Ecuador), in this section has been summarized its application according to conceptual model.

Table 5. Courses of the empirical experience

\begin{tabular}{lllll}
\hline Course & $\mathrm{N}$ & Fem & Experts & Practices \\
\hline $\begin{array}{l}\text { Design- } \\
\text { engineering 1 }\end{array}$ & 63 & 29 & 1 & 7 \\
$\begin{array}{l}\text { Design- } \\
\text { engineering 2 }\end{array}$ & 26 & 5 & 1 & 7 \\
$\begin{array}{l}\text { Pre-primary } \\
\text { education } \\
\text { teaching }\end{array}$ & 24 & 24 & 2 & 1 \\
\hline
\end{tabular}

The rubrics for real time assessment were Content(The content refers to the absolute value and appropriateness of the proposal in relation to its objectives) \& Performance (The performing refers to the correctness attractive and clarity of how the proposal is presented and justified), with values in the scale from 1 to 6 . The courses of design and engineering used the same practices focused in the principles of design, and, the pre-primary education teaching used a practice focused in the project management according to PMbook, it's summarized in table 6 .

Table 6. Practices applied for empirical experience

\begin{tabular}{|c|c|c|}
\hline Course & Practice & Objective \\
\hline \multirow[t]{7}{*}{$\begin{array}{l}\text { Design and } \\
\text { engineering }\end{array}$} & $\begin{array}{l}\text { Business } \\
\text { Opportunity }\end{array}$ & $\begin{array}{l}\text { Proposing a problem for } \\
\text { the practices that should } \\
\text { be used as a referent for } \\
\text { the rest of the practices. }\end{array}$ \\
\hline & $\begin{array}{l}\text { Creative } \\
\text { team }\end{array}$ & $\begin{array}{l}\text { Understand the creativity } \\
\text { from the points of view } \\
\text { of the individual person, } \\
\text { the team and the } \\
\text { organization }\end{array}$ \\
\hline & Idea creation & $\begin{array}{l}\text { Understand the concepts } \\
\text { behind the processes of } \\
\text { creating and } \\
\text { managing ideas }\end{array}$ \\
\hline & $\begin{array}{l}\text { Participative } \\
\text { innovation } \\
\text { space }\end{array}$ & $\begin{array}{l}\text { Understand the model of } \\
\text { "Participative Innovation } \\
\text { Space" (PIS) and the } \\
\text { concepts behind it.. }\end{array}$ \\
\hline & $\begin{array}{l}\text { Design } \\
\text { frontiers }\end{array}$ & $\begin{array}{l}\text { Understand different } \\
\text { approaches to work, and } \\
\text { how the things are done } \\
\text { considering its creation } \\
\text { and/or design. }\end{array}$ \\
\hline & $\begin{array}{l}\text { Think } \\
\text { building }\end{array}$ & $\begin{array}{l}\text { Understand the concept of } \\
\text { Design Thinking (DT), and } \\
\text { the way it works. }\end{array}$ \\
\hline & $\begin{array}{l}\text { Design } \\
\text { process }\end{array}$ & $\begin{array}{l}\text { Understand the concept of } \\
\text { design process and its } \\
\text { connection with business } \\
\text { management. }\end{array}$ \\
\hline
\end{tabular}

\begin{tabular}{lll}
\hline $\begin{array}{l}\text { Pre-primary } \\
\text { education } \\
\text { teaching }\end{array}$ & $\begin{array}{l}\text { Business } \\
\text { opportunities }\end{array}$ & $\begin{array}{l}\text { Understand the importance } \\
\text { of bussines opportunities } \\
\text { identification in the project } \\
\text { management through the } \\
\text { PMBook guide lines. }\end{array}$ \\
\hline
\end{tabular}

It has been possible to extract some patterns from the data and consequently propose a set of Teaching Key Performance Indicators that could help to measure aspects related to collective intelligence. In table 7 we propose the 4 KPI.

\section{Table 7. Indicators that could estimate collective intelligence in education}

\begin{tabular}{|c|c|c|}
\hline $\mathrm{KPI}$ & Type & Description \\
\hline $\begin{array}{l}\text { Value from } \\
\text { ideas }\end{array}$ & Individual & $\begin{array}{l}\text { Score obtained by the } \\
\text { ideas that each individual } \\
\text { student proposed. }\end{array}$ \\
\hline $\begin{array}{l}\text { Accuracy in } \\
\text { assessment }\end{array}$ & Individual & $\begin{array}{l}\text { Deviation between score } \\
\text { assigned by experts and } \\
\text { score assigned by each } \\
\text { student in all the } \\
\text { assessments done during } \\
\text { the practice. }\end{array}$ \\
\hline $\begin{array}{l}\text { Value from } \\
\text { Collective } \\
\text { work }\end{array}$ & Collective & $\begin{array}{l}\text { Score obtained by the } \\
\text { group during the defense } \\
\text { of all the group } \\
\text { proposals. }\end{array}$ \\
\hline $\begin{array}{l}\text { Self- } \\
\text { assessment } \\
\text { accuracy }\end{array}$ & Collective & $\begin{array}{l}\text { Deviation between score } \\
\text { assigned by experts and } \\
\text { score assigned by each } \\
\text { student in all the } \\
\text { assessments done during } \\
\text { the practice }\end{array}$ \\
\hline
\end{tabular}

The list of KPI defined in the table 7, has been created with the information gotten from table 4 (Analytics of the Fabricius Teaching Model) and showed in figures 3 to 6.

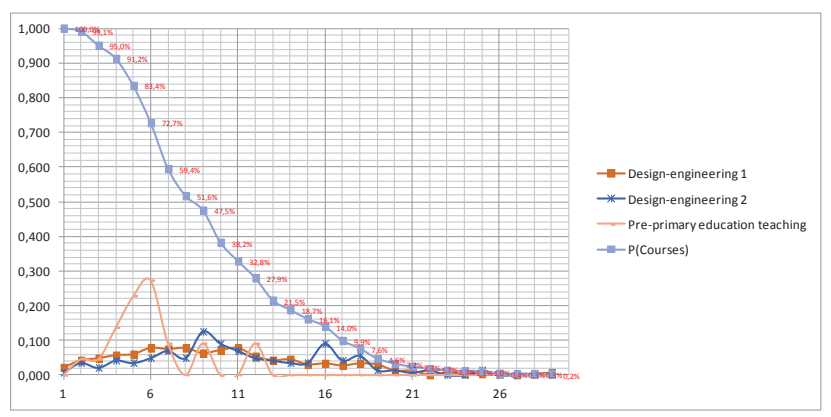

Figure 3. Individual performance

Figure 3 is related with the contributions, a contribution is considered completeness when it has proposed and voted, hence, it's shown the number of votes by ideas proposed. 


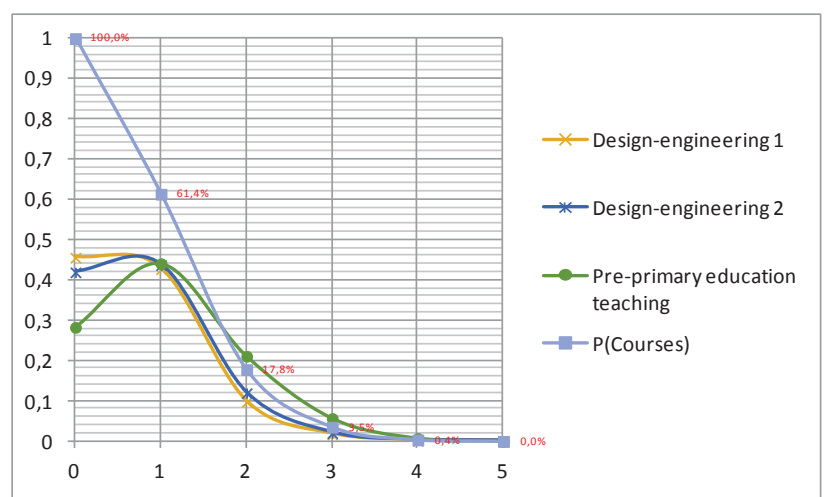

Figure 4. Individual knowledge catching

We consider that when deviation is inversely proportional to Individual knowledge catching, it means that while the student is nearer to zero (0) the knowledge increases, in this sense, was defined a qualitative valuation of deviation (Very Good: 0-0, Good greater than 0-1, Regular greater than 1-2, Bad greater than 23, Very Bad greater than 3-5) table 8, according this criteria $82 \%$ of students has gotten a good valuation.

\section{Table 8. Qualitative valuation range deviation}

\begin{tabular}{lll}
\hline Qualitative Valuation & \multicolumn{2}{c}{ Deviation Range } \\
\cline { 2 - 3 } & From & To \\
\hline Very Good & 0 & 0 \\
Good & greater than 0 & 1 \\
Regular & greater than 1 & 2 \\
Bad & greater than 2 & 3 \\
Very Bad & greater than 3 & 5 \\
\hline
\end{tabular}

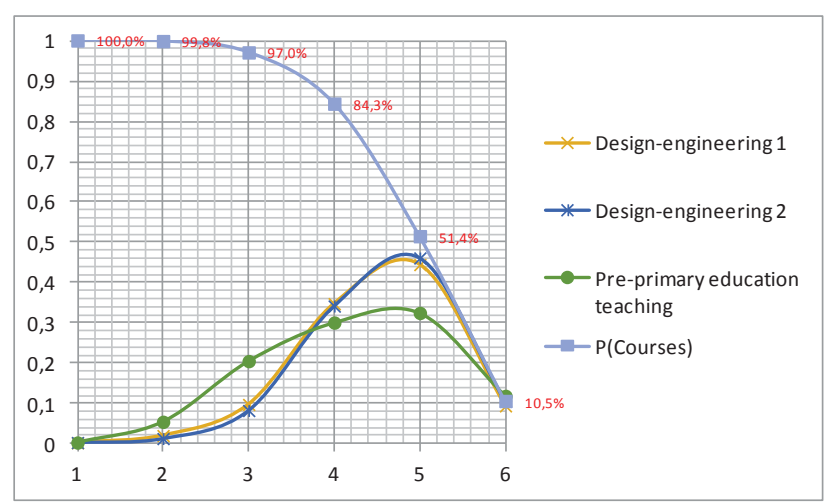

Figure 5. Group dynamics

The consensus evaluation level shown in the figure 5, was voted between the 4 and 5 value of the scale, where $73 \%$ of student have voted in this range.

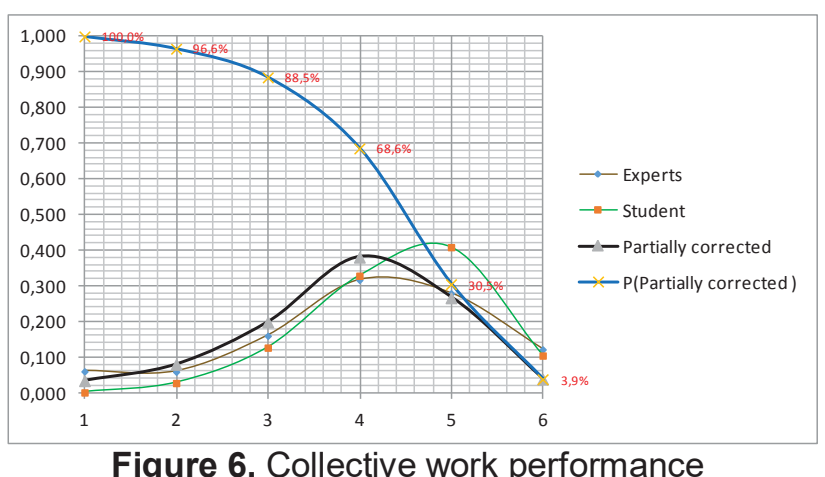

Figure 6. Collective work performance

The figure 6 shown the score of experts student, and also the score partially corrected with score with the students.The score corrected applied the $80 \%$ of weight for experts and $20 \%$ for students, with this adjustment we try reducing the experts subjectivity.

\section{Discussion.}

The educational models used by several years in higher education, has generated some barriers that make it difficult for students, teachers and curricula in general, a highly collaborative model that encourages synergy of equipment, where responsibilities should be given no by the smartest member or by the score obtained on a test, but by the degree to which the group works and shares their results. In this type of scenario, the roles of both teachers and students change, where the teacher becomes an adviser and guide the development of the practice, and the students in the generator of new knowledge. The findings evidenced in practices and the evolution of knowledge, leads to think that it is also necessary to consider increase the skills of collective intelligence for educators [27] in order to achieve a complete learning process. Moreover, the growth generated by the emergence of Web 2.0, MOOCs among others information resource, would be an improvement in the way of teaching, however it is not used the maximal potential, because the teaching models used are centred in the individual. Toward future, these tools should be become not only how a support to education, but also how a element of the educational core, that foster a new style for teaching and learning centred in the collective performance.

This article has shown partial results in the process of educating the collective intelligence with the use of ICT, however the experimental field should be expanded to various thematic areas and cultures, to be able to generalize the results. Indicators of collective intelligence shown in Table 7, will be detailed in future trials. 


\section{Conclusions.}

The outcomes about the group dynamics and collective work performance, show some evidence about student engagement \& empowerment, as well as the increase of attention during the class.

The analysis of application of collective intelligence education through the ICT internet tools, allows the reader to know some evidence about of this emergent field, offering help and guidance to researchers in their work.

Fabricius makes it feasible to apply a level of transparency and participation in the teaching-learning process that facilitates collective intelligence. Fabricius allow the real time calculation of collective intelligence elements that encourage the commitment of students in the learning process. More in detail, we concluded that the this kind of tools effectively facilitate open management of ideas and real time collaborative assessment of work done in the class

The experience presented shown the great potential that exists for research in the field of Collective Intelligence in Education, which requires various groups and longer periods of time, to allow get new conclusions and hypotheses that support the process of teaching and learning in higher education.

With future vision, will be interesting to continue analyzing in deep the collective intelligence influence in group performance and the correlation with the individuals profiles, trying to find patterns for the most efficient group formation and performance based on paradigms of collective intelligent.

\section{Appendix A. Fabricius Interfaces}

To follow we presented the main interfaces used by Fabricius and some characteristics summarized in table 9.

Table 9. Main Fabricius characteristics

\begin{tabular}{lll}
\hline Name & Kind & Description \\
\hline Highly & Technical & Lets adjust the \\
parameterized & & parameters for different \\
& countries, institutions, \\
& experts, practices, \\
& surveys, rubrics and \\
& collaborative \\
& application contained in \\
& the Fabricius suite. \\
& Its architecture lets the \\
Integration & publication of new web \\
with mobile & services and configure \\
technologies. & easily the users \\
& & interfaces from different \\
& technologies. \\
\hline
\end{tabular}

\begin{tabular}{|c|c|c|}
\hline $\begin{array}{l}\text { Transaction } \\
\text { database }\end{array}$ & & $\begin{array}{l}\text { Lets increasing the } \\
\text { number of users and } \\
\text { transaction, } \\
\text { incrementing the } \\
\text { physical server, or } \\
\text { database clusters. }\end{array}$ \\
\hline Supervision & Educational & $\begin{array}{l}\text { Full control about the } \\
\text { group work during all } \\
\text { the stages of the } \\
\text { practice. Furthermore } \\
\text { the work done by } \\
\text { students in the projects } \\
\text { is converted in case- } \\
\text { examples of the } \\
\text { content }\end{array}$ \\
\hline $\begin{array}{l}\text { Real time } \\
\text { assessment }\end{array}$ & & $\begin{array}{l}\text { Systematic real time } \\
\text { assessment of the } \\
\text { content }\end{array}$ \\
\hline $\begin{array}{l}\text { Serious } \\
\text { games }\end{array}$ & & $\begin{array}{l}\text { Online serious game } \\
\text { using competition- } \\
\text { motivation strategies }\end{array}$ \\
\hline Collaboration & & $\begin{array}{l}\text { Engagement and } \\
\text { participation during the } \\
\text { class } \\
\text { Empowerment and } \\
\text { participation during all } \\
\text { the process }\end{array}$ \\
\hline $\begin{array}{l}\text { Patterns \& } \\
\text { forecasting }\end{array}$ & & $\begin{array}{l}\text { Pattern recognition and } \\
\text { forecasting for the next } \\
\text { practices }\end{array}$ \\
\hline Alerts & & $\begin{array}{l}\text { Continuously alerts to } \\
\text { experts \& students } \\
\text { about scheduling, } \\
\text { moreover about some } \\
\text { rare behaviour } \\
\text { identified in real time } \\
\text { from the pattern } \\
\text { recognition machine. }\end{array}$ \\
\hline
\end{tabular}

Fabricius was developed using a incremental-design, where each user interaction lets improve the software components.

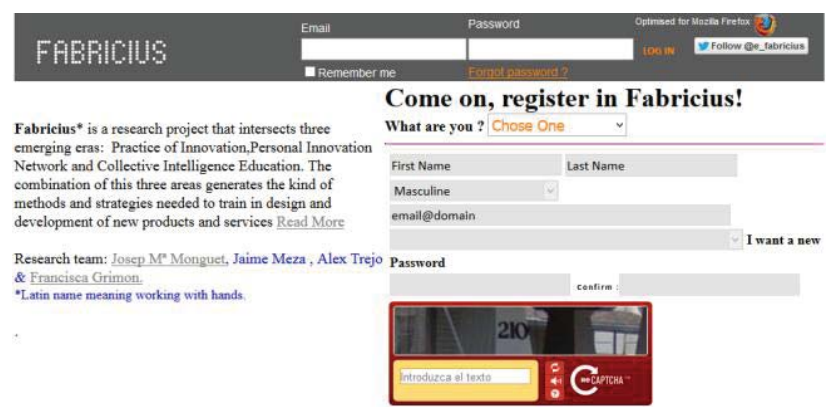

The home page presented below shows a list of stages to develop, according to the proposal teaching model, however the software lets be used all the framework or some application, according its needs. By each stage is shown the corresponding application according to the software parameters for the institution and practice. 


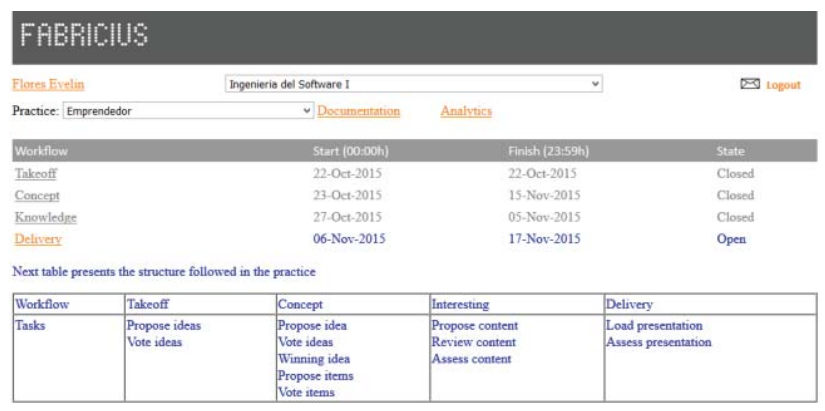

For finish, let's show the main interface of Miningant, it's allowed us obtain some analytics for improve in each iteration the practices..

\section{Minant}

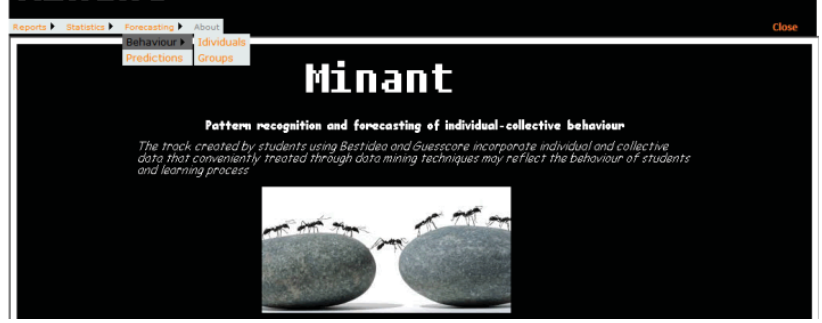

\section{Acknowledgements.}

We want to thank students from Universitat Politécnica de Catalunya UPC- Spain \& Universidad de las Fuerzas Armadas ESPE - Ecuador, that used Fabricius for the support to this research.

\section{References}

[1] Y. M. Gilliver, R. S., Randall, B., \& Pok, "Learning in cyberspace: Shaping the future," J. Comput. Assist. Learn., vol. 14, pp. 212-222, 1998.

[2] $\mathrm{H}$. $\mathrm{Li}$ and $\mathrm{Z}$. Li, "Emergence of collective intelligence in distance education system," in 2010 2nd International Conference on Education Technology and Computer, 2010, vol. 1, pp. V1-333-V1-337.

[3] B. Cornu, "Collective intelligence and capacity building," in Education and the Knowledge Society SE - 3, vol. 161, T. van Weert, Ed. Springer US, 2005, pp. 27-34.

[4] P. Lévy, "From social computing to reflexive collective intelligence: the IEML research program," Inf. Sci. (Ny)., vol. 180, no. 1, pp. 71-94, Jan. 2010.

[5] P. Lévy, "Toward a Self-referential Collective Intelligence Some Philosophical Background of the IEML Research Program," in First International Conference, ICCCI 2009, 2009, vol. 5796, pp. 22-35.

[6] E. Bonabeau, "Decisions 2 . 0: The Power of Collective Intelligence," MIT Sloan Management Review, vol. $50 \mathrm{~N}$. 02, no. 50211, Massachusetts, 2009.

[7] F. Gónzalez, V., Silvana, "PROCESOS DE INTELIGENCIA COLECTIVA Y COLABORATIVA EN EL MARCO DE TECNOLOGÍAS WEB 2 . 0 :, PROBLEMAS Y APLICACIONES," Fac. Psicol. - UBA / Secr. Investig. / Anu. Investig., vol. XIX, pp. 253-270, 2012.
[8] W. Tsai, W. Li, and J. Elston, "Collaborative Learning Using Wiki Web Sites for Computer Science Undergraduate Education: A Case Study," IEEE Trans. Educ., vol. 54, no. 1, pp. 114-124, 2011.

[9] Z. Petreski, H., Tsekeridou, S., Giannaka, E., Rashmi Prasad, N., Prasad, R., \& Tan, "Technology enabled social learning: A review," Int. J. Knowl. Learn., pp. 7(3/4), 253270, 2011.

[10] C. Thompson, K. Gray, and H. Kim, "How social are social media technologies (SMTs)? A linguistic analysis of university students' experiences of using SMTs for learning," Internet High. Educ., vol. 21, pp. 31-40, 2014.

[11] I. Paus-Hasebrink, C. W. Wijnen, and T. Jadin, "Opportunities of Web 2.0: Potentials of learning," Int. J. Media Cult. Polit., vol. 6, no. 1, pp. 45-62, 2010.

[12] D. C. Engelbart, "Toward augmenting the human intellect and boosting our collective IQ," Commun. ACM, vol. 38(8), pp. 30-32, 1995.

[13] A. W. Woolley, C. F. Chabris, A. Pentland, N. Hashmi, and T. W. Malone, "Evidence for a collective intelligence factor in the performance of human groups.," Science, vol. 330 , no. 6004, pp. 686-8, Oct. 2010.

[14] J. B. Barlow and A. R. Dennis, "Not as Smart as We Think: A Study of Collective Intelligence in Virtual Groups," Collect. Intell. 2014, pp. 1-5, 2014.

[15] P. Gallardo, A. Hernandez G, and Robles G Cortes, "Collective intelligence as mechanism of medical diagnosis," Expert Syst. with Appl. 40, vol. 2726-2737, 2013.

[16] L. Ilon, How collective intelligence redefines education, vol. 113. Berlin, Heidelberg: Springer Berlin Heidelberg, 2012.

[17] Capterra, "Best Ideas Management Software." [Online]. Available: www.capterra.com/idea-management-software/.

[18] "CATALYST." [Online]. Available: http://catalystfp7.eu/open-tools/.

[19] L. Veilleroy, Y.; Hoogstoel, F.; Lancieri, "QLIM -- A Tool to Support Collective Intelligence," Privacy, Secur. Risk Trust (PASSAT), 2012 Int. Conf. 2012 Int. Confernece Soc. Comput., p. 322,327, 2010.

[20] C. C. I. MARTÍ, T., MONGUET, J. M., TREJO, A., ESCARRABILL, J., \& BEITIA, "Collective health policy making in the Catalan Health System: applying Health Consensus to priority setting and policy monitoring," Collect. Intell. 2014, pp. 1-5, 2014.

[21] I.-A. Chounta and N. Avouris, "It's All about Time: Towards the Real-Time Evaluation of Collaborative Activities," 2014 IEEE 14th Int. Conf. Adv. Learn. Technol., pp. 283-285, 2014.

[22] G. Mathioudakis and A. Leonidis, "Real-Time Teacher Assistance in Technologically-Augmented Smart Classrooms,” Int. J. Adv. Life Sci., vol. 6, no. 1, pp. 62-73, 2014.

[23] Monguet, Josep M., and Jaime Meza. "Guess the Score, Fostering Collective Intelligence in the Class." E-Learning, E-Education, and Online Training. Springer International Publishing, 2014. 116-122.

[24] M. Jordan and J. Kleinberg, Information Science and Statistics, vol. 4. 2006.

[25] E. Fahlbusch, L. Vischer, J. M. Lochman, J. S. Mbiti, and J. Pelikan, "Llullian Method," in The Encyclopedia of Christianity, 2003, pp. 331-332.

[26] N. Harvey and C. a. Holmes, "Nominal group technique: An effective method for obtaining group consensus," Int. J. Nurs. Pract., vol. 18, no. 2, pp. 188-194, 2012. 
[27] Levy, Pierre. "Collective Intelligence for Educators." Educational Philosophy and Theory 47.8 (2015): 749-754. 